Sebastian Chudak

Uniwersytet im. Adama Mickiewicza w Poznaniu https://orcid.org/0000-0003-3026-9388 s.chudak@amu.edu.pl

\title{
Techniki ewaluacji kompetencji międzykulturowej: Założenia teoretyczne a praktyka projektu edukacyjnego Connect
}

\begin{abstract}
Evaluation techniques for intercultural competence:
Theoretical assumptions and practice in the educational project connect

In academic education there is an increased emphasis on curricula with activities that stimulate the acquisition of knowledge, development of skills and shaping of attitudes that are needed during intercultural meetings. Although the discussion on the substantive and methodological aspects of intercultural education, which has been going on for several decades, has raised many theoretical considerations and led to practical solutions, the issue of the evaluation of intercultural competences still remains quite problematic. What is intercultural competence? How can it be measured? What tools should be used for this? How can their relevance and reliability be measured? These issues are discussed in the context of the European educational Erasmus+ project Connect (2015-2018).
\end{abstract}

Keywords: intercultural experiences, intercultural reflexion, intercultural competence, evaluation, project, Erasmus+

Słowa kluczowe: doświadczenia międzykulturowe, refleksja międzykulturowa, kompetencja międzykulturowa, ewaluacja, projekt, Erasmus+ 


\section{Wstęp}

Od 1987 r. rokrocznie tysiące studentów ze wszystkich krajów członkowskich Unii Europejskiej uczestniczą w programie Erasmus (od 2014 r. Erasmus+) studiując, odbywając staże i pracując poza granicami swojej ojczyzny. Program ten, który funkcjonuje w ramach Unii Europejskiej już od ponad 30 lat, „zmienia życie" i „otwiera umysły” (zob. http://erasmusplus.org.pl, stan z dnia 30.09.2018; Dąbrowska-Resiak, 2018), jest też oceniany jako jeden z najlepszych programów unijnych. Świadczą o tym m.in. dane liczbowe, które w istocie są imponujące:

_ już w 2012 r. budżet programu opiewał na kwotę 2,2 mld euro, w roku 2018 miał natomiast osiągnąć rekordowy pułap 2,7 mld euro;

- w 2002 r. dzięki programowi Erasmus aż milion studentów mogło spędzić co najmniej jeden semestr na uczelniach zagranicznych; w 2013r - przekroczono liczbę $3 \mathrm{mln}$, zaś w 2017 r. - 4,4 mln; jeszcze raz tyle osób skorzystało $z$ innych ofert dostępnych $w$ ramach programu (por. Ehrhardt, 2018: 1-2);

- w Polsce od momentu przystąpienia do programu w roku akademickim 1989/99 widoczny jest stały wzrost zainteresowania uczestnictwem w nim: 1426 uczestników w pierwszym roku; w 2014 r. już 15521 uczestników, co oznacza wzrost o $1100 \%$ (zob. Chudak, Mackiewicz, 2018: 36).

Czy można jednak powiedzieć, że program ten to sukces? Gdyby próbować odpowiedzieć na to pytanie, patrząc na zagadnienie przez pryzmat wymienionych wyżej liczb osób w nim partycypujących, można by zapewne zaryzykować odpowiedź twierdzącą. Nie bez przyczyny mówi się nawet o „pokoleniu Erasmusa" (zob. Gaworska, 2017), a kontekst, w którym pojawia się to określenie jest zawsze zdecydowanie pozytywny (zob. Ehrhardt, 2018: 6). Czy jednak efekty, które program przynosi, są optymalne i maksymalne? Czy nie oceniamy ich z nadmiernym optymizmem?

Nie ulega wątpliwości, że potencjalnie korzyści dla uczestników programu są liczne. Jest to np.:

- poprawa perspektyw zawodowych (tzw. employability = zatrudnialność) poprzez rozwój szerokiej gamy tzw. kompetencji kluczowych (w tym np. umiejętności pracy w zespołach wielokulturowych);

- rozwój kompetencji językowych (wielojęzyczność);

- rozwój kompetencji międzykulturowej w zakresie wiedzy, umiejętności i postaw (w tym np. tolerancji czy otwartości wymienianych jako jej konstytucyjne części składowe) poprzez: zanurzenie się w obcej kulturze, doświadczenia związane z bezpośrednimi kontaktami z przedstawicielami różnych/obcych kultur oraz doświadczenie obcości/szoku kulturowego, 
które mogą stać się bodźcem do refleksji na temat własnego tła kulturowego i innych kultur.

Wpływ mobilności na rozwój zawodowy uczestników programu był przedmiotem różnorodnych badań, w tym badania The Erasmus Impact Study (Brandenburg i in., 2014, 2016), które potwierdziło, że studenci korzystający z oferty programu Erasmus rozwijają takie cechy, jak np. otwartość, kreatywność, elastyczność czy empatia, a także umiejętności komunikacyjne oraz krytycznego myślenia w stopniu znacznie większym niż ich rówieśnicy, którzy nie uczestniczą w programie, a to pozytywnie wpływa na ich szanse na rynku pracy:

On average, Erasmus students have better employability skills after a stay abroad than $70 \%$ of all students. Based on their personality traits, they have better a better predisposition for employability eve before going abroad. By the time they return they have increased their advantage by $42 \%$ an average. [...] While $64 \%$ of employers consider an international experience as important for recruitment, on average 92\% are looking for transversal skills such as openness to and curiosity about new challenges, problem-solving and decision-making skills, confidence, tolerance towards other personal values and behaviours (Brandenburg i in., 2014: 3).

W przypadku kompetencji językowych zakłada się często, że ich przyrost przyniesie sam pobyt w kraju, gdzie mówi się językiem, którego nauką jest się zainteresowanym. Wiele badań dowodzi, iż faktycznie tak się dzieje. Tak np. z badań opisywanych przez Dąbrowską-Resiak (2018: 40) wynika, że „niemal trzy czwarte ankietowanych [stypendystów programu Erasmus] uznało, że poprawa znajomości języków obcych stanowi największą korzyść z wyjazdu". Wskazuje się jednak jednocześnie na to, że progresja następuje jedynie w niektórych obszarach (poszerzenie słownictwa, rozwój sprawności słuchania ze zrozumieniem i mówienia; zob. Kováčová, Kopčová, 2018: 15f.). Poddawani badaniom studenci w kontekście stosowanych przez siebie strategii uczenia się wskazują na rolę kontaktów z rodzimymi użytkownikami języka, które choć stanowią dla wielu z nich spore wyzwanie, to jednak - wydają się mieć szczególnie pozytywny wpływ na takie aspekty, jak np. płynność wypowiedzi, szybkość reakcji podczas prowadzenia dialogów, dopasowanie użytego słownictwa do danego kontekstu (ibid.: 31-32). Choć brak niestety precyzyjnych danych odnośnie do efektywności kursów językowych oferowanych studentom w czasie ich pobytów na zagranicznych uczelniach, pozytywnie należy ocenić jednak fakt, że mogą oni w takich kursach brać udział.

W kontekście ostatniej z wymienionych powyżej kompetencji, tj. kompetencji miedzykulturowej zachodzi niestety uzasadniona obawa, że - choć 
wielu stypendystów programu Erasmus deklaruje, iż doświadczenie wyjazdu na zagraniczne stypendium i nauki lub pracy w środowisku międzykulturowym przyczyniło się u nich do zdobycia kompetencji kulturowych (zob. DąbrowskaResiak, 2018: 105 i nn.), to - w wielu przypadkach (może nawet w większości) efekty pobytu za granicą pozostają dość przypadkowe. Przypuszczenie to wynika z braku odpowiedniego wsparcia pedagogiczno-dydaktycznego, przede wszystkim zaś jakiegokolwiek, tym bardziej zaś zindywidualizowanego, mentoringu, w ramach którego studenci uczestniczący w wymianie byliby przygotowywani do wyjazdu za granicę oraz wspierani podczas pobytu w wybranym przez siebie kraju i po jego zakończeniu (por. Holfter, Rieder, 2018: 69). Przykłady programów tego typu lub materiałów adresowanych do studentów są zdecydowanie rzadkie, jednostkowe. Warto więc wspomnieć o zrealizowanym w Niemczech we współpracy między uniwersytetami w Hamburgu, Kassel i Siegen projekcie „MuMiS: Mehrsprachigkeit und Multikulturalität im Studium” (Schumann, 2012; http://www.mumis-projekt.de, czy o publikacji „Eine Frage der Perspektive. Critical Incidents aus Studentenwerken und Hochschulverwaltung. 30 Fallbeispiele aus der Praxis mit 93 interkulturellen Einschätzungen von Studierenden und Mitarbeitenden" (Hiller, 2016).

Kompetencja międzykulturowa należy do kompetencji 'miękkich', których znaczenie podkreśla się zarówno w dokumentach opisujących cele kształcenia językowego, jak i w codziennej praktyce organizacji działających w otoczeniu wielokulturowym. Także w kształceniu akademickim obserwuje się zwiększony nacisk na włączanie w programy nauczania aktywności stymulujących zdobywanie wiedzy, rozwój sprawności i kształtowanie postaw pożądanych w trakcie spotkań międzykulturowych (zob. np. Karpińska-Musiał, 2015: 39 i nn.). Według projektu INCA (2004), o którym wspominamy później, kompetencja międzykulturowa uwzględnia sześć wymiarów: tolerancję niejednoznaczności, elastyczność behawioralną, świadomość komunikacyjną, zdobywanie wiedzy, otwartość wobec innych kultur oraz empatię. Aby doświadczenia zdobyte przez stypendystów programu Erasmus przyniosły efekty pożądane w kontekście rozwijania tej kompetencji w każdym z tych wymiarów, konieczne wydaje się zaoferowanie jego uczestnikom odpowiedniego wsparcia.

W tym kontekście powstała więc idea stworzenia kompleksowego programu Connect i narzędzi, które umożliwiłyby przygotowanie osób wyjeżdżających na zagraniczne uczelnie do radzenia sobie w nowych warunkach, ale przede wszystkim zmaksymalizowanie pozytywnych efektów doświadczeń zebranych w trakcie wyjazdu. Celem niniejszego artykułu jest krótka prezentacja jego koncepcji i refleksja nad możliwościami ewaluacji kompetencji międzykulturowej, która dzięki niemu się rozwinęła. 


\section{Connect. Intercultural Learning Network}

Connect to międzynarodowy projekt zainicjowany w roku 2015 i realizowany w kolejnych trzech latach ze środków programu Erasmus+ (szczegółowy opis kolejnych faz projektu i jego rezultaty pod adresem http://weconnecteurope.eu, stan z dnia 19.02.2020) przy współpracy dziesięciu instytucji (w tym ośmiu uczelni wyższych) z siedmiu krajów UE:

- AFS Interkulturelle Begegnungen e.V. (Hamburg, Niemcy),

- Friedrich-Schiller-Universität (Jena, Niemcy),

- Haaga-Helia University of Applied Sciences (Helsinki, Finlandia),

- InterCultur (Hamburg, Niemcy),

- Karlshochschule International University (Karlsruhe, Niemcy),

- Universita Degli Studi Di Urbino Carlo Bo (Urbino, Włochy),

- Universitat De Vic. Universitat Central de Catalunya (Vic, Hiszpania),

- Universitatde Fernando Pessoa (Porto, Portugalia),

- University of Limerick (Limerick, Irlandia),

- Uniwersytet im. Adama Mickiewicza (Poznań, Polska).

Miał on na celu stworzenie innowacyjnego i wychodzącego naprzeciw potrzebom pokolenia digital natives (i problemom sygnalizowanym przez jego przedstawicieli) scenariusza kształcenia międzykulturowego i narzędzi potrzebnych do jego realizacji, tj.:

- programów treningów międzykulturowych prowadzonych face2face przed wyjazdem (pre-departure) i po powrocie z niego (re-orientation),

- platformy e-learningowej, na której umieszczono tzw. modules, tj. pogrupowane w sześć bloków tematycznych materiały przeznaczone do pracy samodzielnej $w$ ramach virtual learning podczas pobytu za granicą,

- dostępnej online interaktywnej aplikacji Experience Map.

Poszczególne komponenty programu Connect pozwalają na kompleksowe, rozłożone w czasie i solidnie podbudowane metodycznie szkolenie kompetencji międzykulturowej studentów międzynarodowych.

\subsection{Trening przed wyjazdem (Pre-departure training-face2face)}

Trening face2face prowadzony przed wyjazdem za granicę rozwija refleksyjność i wrażliwość (między)kulturową. Składa się on z czterech bloków tematycznych. Ich przedmiotem jest: 
1. refleksja nad pojęciem kultura, własną tożsamością kulturową i postrzeganiem samego siebie oraz oczekiwań i indywidualnych celów związanych z wyjazdem;

2. refleksja na temat różnych aspektów komunikacji międzykulturowej oraz rozwój strategii komunikacyjnych pomagających w efektywnym pokonywaniu różnych trudności pojawiających się w kontaktach z przedstawicielami innych kultur;

3. refleksja nad strukturą wiedzy, stereotypami i uprzedzeniami, nad własną wiedzą o kraju docelowym i jego mieszkańcach;

4. kompetencja narracyjna i medialna; rozwijanie wrażliwości studentów jako przyszłych autorów treści umieszczanych na Experience Map i platformie e-learningowej.

O świadomej refleksji nad językiem i kulturą mówi się jako o czynniku przyczyniającym się do podniesienia efektywności procesu uczenia się i sukcesu uczącego się dzięki jego aktywizacji oraz do kształtowania postawy lifelong learning (por. Myczko, 2005). Jest to szczególnie istotne wobec faktu, że w trakcie nauki w szkole czy też w ramach kursów językowych uczący nabywają jedynie swego rodzaju initial competence, a nad professional competence muszą pracować sami przez całe życie. $Z$ drugiej jednak strony wskazuje się na znikomą ilość form pracy, które przyczyniałyby się do zwiększenia refleksyjności uczniów, oraz na to, że nauczyciele niejednokrotnie nie są wystarczająco przygotowani do tego, aby wspierać taką ich postawę (por. Chudak, 2013: 221-223). Nazarkiewicz (2016) postuluje, z czym się zgadzamy, zastąpienie dotychczasowego pojęcia interkulturowości, a tym samym kompetencji międzykulturowej przez kulturowq refleksyjność, gdyż zajmując się kulturą i porównywaniem kultur trudno o proste, jednoznaczne odpowiedzi. Zamiast nich uczący się odkrywa różne płaszczyzny zjawisk kulturowych i napotyka na różnorodność interpretacji. Nie jest wobec tego możliwe wyposażenie go w wiedzę i umiejętności, które zapewniłyby mu powodzenie w każdej sytuacji komunikacyjnej, w jakiej potencjalnie może się znaleźć. Celowa jest zatem refleksja na temat tego, dlaczego interpretuje pewne zjawiska tak a nie inaczej, co wpływa na jego własne zachowanie, jakie strategie mogą być pomocne w rozwiązywaniu problemów, na które napotka.

\subsection{Experience Map}

Experience Map przypomina na pierwszy rzut oka mapy Google. Różni się jednak od nich znacząco dzięki specyficznym funkcjom. Umożliwia ona bowiem dodawanie raportów (tekstów, zdjęć, nagrań audio lub wideo) z opisami własnych 
doświadczeń związanych z pobytem na uczelni zagranicznej. Studenci planujący wyjazd za granicę w ramach programu Erasmus mogą dzięki temu narzędziu uzyskać aktualne informacje na temat interesującej ich uczelni (w tym różnych spraw dotyczących formalności, toku studiów, w tym wyboru przedmiotów, warunków zaliczenia zajęć itp.) oraz życia w mieście i kraju, do którego mają zamiar się udać (np. warunków mieszkaniowych czy transportu publicznego). Mogą również nawiązać kontakt z uczestnikami programu Erasmus obecnie mieszkającymi i studiującymi w wybranych przez nich miejscach. Wszystko to wychodzi naprzeciw potrzebom sygnalizowanym przez studentów (zob. Holfter, Rieder, 2018: 70f) i ma służyć ułatwieniu im (rozpoczęcia) pobytu w nowym, obcym miejscu.

W części 'offcial links' na Experience Map znaleźć można informacje dotyczące np.: uczelnianych działów współpracy z zagranicą, mieszkania, transportu, spraw istotnych w pierwszych dniach po przyjeździe, aktualnych wydarzeń kulturalnych, służby zdrowia, wykładów, działania bibliotek, „przetrwania na uczelni”, zakupów, możliwości nauki języka, form spędzania wolnego czasu i restauracji. W części „experiences" studenci dzielą się swoimi własnymi doświadczeniami zdobytymi podczas pobytu w danym mieście czy kraju. Ich spektrum jest szerokie i obejmuje zarówno praktyczne informacje na temat możliwości znalezienia mieszkania, zrobienia niedrogich zakupów lub zjedzenia dobrego i taniego posiłku, jak i pogłębione refleksje na temat zachowań specyficznych dla mieszkańców danego kraju.

\subsection{Moduły (virtual learning/online support)}

Moduły online poruszają szereg tematów międzykulturowych i zawierają ćwiczenia interaktywne. Pierwszy z sześciu modułów zatytułowany Hungry for new experiences \& key concepts, z którym studenci pracują jeszcze przed wyjazdem, ma na celu zachęcenie ich do samodzielnego eksplorowania Experience Map i szukania alternatywnych źródeł informacji na temat przyszłego miejsca ich pobytu. Praca z poszczególnymi modułami wspiera ich w pokonywaniu różnego rodzaju trudności związanych z pobytem za granicą. Po powrocie do domu mają zaś do dyspozycji ostatni moduł online: Coming home, thinking back and moving forward. Jego celem jest retrospekcyjny przegląd doświadczeń, wrażeń i spostrzeżeń zebranych podczas wyjazdu oraz ponownie refleksja - tym razem na temat tego, jak wykorzystywać w przyszłości zdobytą wiedzę i umiejętności.

\subsection{Trening po powrocie (re-entry training - face2face)}

Re-entry training to część programu poświęcona ewaluacji zebranych doświadczeń międzykulturowych, transferowi wiedzy, nawiązywaniu kontaktów i przygotowaniu do działalności mentorskiej. Także tu osią wszystkich działań jest refleksja, m.in. nad 
doświadczonym szokiem kulturowym, strategiami radzenia sobie z nim i powrotu do codzienności, obecnością elementów obcokulturowych w ich rodzimym otoczeniu, propagowaniem wielokulturowości i otwartości na różnorodność kulturową w ich własnym środowisku. Ważnym punktem jest tu także wzbogacanie swojego CV (lub portfolio) o informacje dotyczące umiejętności zdobytych w trakcie pobytu za granicą, które mogą zwiększyć ich szanse na rynku pracy. Końcowy komponent to informacja o tym, jak samemu zostać mentorem w ramach Connect.

\subsection{Podsumowanie}

Podczas pobytu na uczelni goszczącej studenci mogą zatem zostać współtwórcami Experience Map. Ponadto mogą wziąć udział w modułach online poświęconych kompetencji międzykulturowej i storytellingowi oraz umieszczać swoje własne wpisy na Experience Map. Uczestnicy programu uczeni są pisania raportów w sposób nieoceniający, wolny od uprzedzeń, a tym samym zapewniający innym studentom rzetelne informacje przydatne przy wyborze miejsca studiów za granicą. Po zakończeniu udziału w programie otrzymują certyfikat potwierdzony przez uczelnię macierzystą i (ewentualnie) punkty ECTS. Po powrocie bardziej zaangażowani studenci mogą przyjąć rolę mentora na swoim wydziale lub w odpowiednim biurze współpracy z zagranicą, pomagając kolejnym studentom wyjeżdżającym do zagranicznej uczelni partnerskiej. W ten sposób możliwe jest uzyskanie Certyfikatu Mentoringu Międzykulturowego (Certificate for Intercultural Mentoring).

Korzyści dla studentów i uczelni wynikające z uczestnictwa w programie są wielorakie. Najistotniejsze z nich to:

- wkład w internacjonalizację i cyfryzację życia uniwersyteckiego;

- pozyskiwanie aktualnych i precyzyjnych informacji dotyczących warunków studiowania na uczelniach partnerskich i życia w krajach docelowych;

- uzyskanie informacji zwrotnej od studentów podczas ich pobytu na danej uczelni i po jego zakończeniu;

- ułatwienie pracy uczelnianych działów współpracy z zagranicą i biur Erasmus poprzez system monitoringu peer-to-peer;

- możliwość zdobycia dodatkowych kwalifikacji przez studentów (Certificate of Intercultural Mentoring).

\section{Ewaluacja kompetencji międzykulturowej}

Jakakolwiek sytuacja testowa, egzaminacyjna czy treningowa nie daje gwarancji sprowokowania prawdziwych reakcji i/lub postaw jej uczestnika, zaś faktyczna kompetencja interkulturowa lub jej deficyty ujawniają się w pełnej krasie dopiero w chwili próby, jaką jest autentyczne spotkanie interkulturowe (zob. Wilczyńska, 
Mackiewicz, Krajka, 2019: 640). Głównym problemem związanym z ewaluacją kompetencji międzykulturowej jest mniejsza mierzalność (pod)kompetencji międzykulturowych niż kompetencji językowych, do pomiaru których opracowano szereg trafnych i rzetelnych testów kompetencyjnych (zob. np. Błażek, 2008: 110 i nn.). W miarę rzetelne sprawdzenie kompetencji międzykulturowej winno uwzględniać włączenie danej osoby w realne sytuacje interakcyjne w kontekście międzykulturowym, a to nie zawsze jest możliwe.

Większość dotychczasowych instrumentów ewaluacyjnych ma głównie charakter autoewaluacji, są to $\mathrm{np}$. The Cross-Cultural Adaptability Inventory (CCAI) ${ }^{1}$ czy The International Profiler (TIP) ${ }^{2}$. Bardziej złożonym, nieograniczającym się do autoewaluacji a tym samym obiektywniejszym instrumentem ewaluacji kompetencji międzykulturowej jest Intercultural Competence Assessment (INCA 2004). W ramach europejskiego projektu finansowanego ze środków programu Leonardo da Vinci opracowano szczegółowy system opisu kompetencji międzykulturowej, częściowo opartą na sieci internetowej procedurę jej testowania, certyfikat dokumentujący poziom tej kompetencji oraz przygotowano portfolio obejmujące paszport, biografię i dossier samej kompetencji. Warto zaznaczyć, że koncepcja kompetencji międzykulturowej, do którego nawiązuje INCA, opiera się częściowo na bardzo wpływowym wśród dydaktyków języków obcych modelu Byrama (1997).

Na testy oceniające cząstkowe kompetencje interkulturowe składają się (1) pytania ankietowe dotyczące życia zawodowego i doświadczeń międzykulturowych osoby testowanej, (2) scenariusze przedstawiające określone sytuacje międzykulturowe, z którymi powiązane są kolejne pytania, oraz (3) scenki, w których osoba egzaminowana wchodzi w interakcje z egzaminatorem. Dzięki takiemu kompleksowemu testowi możliwe jest określenie stopnia kompetencji międzykulturowej. INCA (2004: 9) wyznacza je trzy:

- niska kompetencja: osoby na tym poziomie już robią postępy; są one gotowe konstruktywnie reagować na daną sytuację; ich odpowiedzi są jednak niesystematyczne, improwizowane i nie opierają się na zasadach, nawet jeśli pomagają uniknąć krótkoterminowych trudności; są one oparte na niepełnych informacjach;

- średnia kompetencja: osoby na tym poziomie zaczynają stosować proste zasady do sytuacji i nie reagują już w sposób improwizowany na odosobnione cechy sytuacji; dysponują oni podstawową strategią i spójną wiedzą o tym, jak zachowywać się w danej sytuacji;

\footnotetext{
1 The Cross-Cultural Adaptability Inventory: https://www.creativeorgdesign.com/tests page.php?id=75.

2 The International Profiler: https://www.communicaid.com/cross-cultural-training/ the-international-profiler/.
} 
- wysoka kompetencja: osoby na tym poziomie podchodzą do sytuacji strategicznie i zasadniczo; przyjmują rolę mediatora w dążeniu do znalezienia najlepszego rozwiązania; ich wiedza o kulturze własnej $i$ innych, w tym o parametrach pracy, jest spójna i wysoko rozwinięta.

W przypadku koncepcji INCA także można mieć wątpliwości odnośnie do mierzalności kompetencji międzykulturowej. Niewątpliwą wartością tego narzędzia jest jednakże pobudzenie refleksyjności egzaminowanych osób, głównie poprzez kompletowanie portfolio.

\section{Ewaluacja kompetencji międzykulturowej w projekcie Connect}

Na rozwój postawy refleksyjnej studenta wobec swojej wiedzy, reakcji emocjonalnych i zachowań w kontekstach oraz sytuacjach międzykulturowych stawiają także bardzo mocno narzędzia ewaluacyjne zastosowane w ramach projektu Connect. Do ewaluacji kompetencji międzykulturowej polskich uczestników programu Erasmus objętych projektem Connect w jego fazie pilotażowej zastosowano kwestionariusz mapowania świadomości kulturowej (Chudak, Mackiewicz, 2018). Kwestionariusz ten wystąpił w dwóch wariantach: pierwszy wykorzystano przed wyjazdem za granicę (pre-departure), drugi zaś w końcowym etapie oceny, czyli po powrocie (re-entry). Celem tak przeprowadzonego badania o charakterze jakościowym było prześledzenie zmiany w świadomości i tożsamości kulturowej studentów uczestniczących w programie wymiany Erasmus. Oba kwestionariusze stanowiły także impuls do (auto)refleksji wykazującej potencjalny rozwój kompetencji międzykulturowej oraz modyfikację i/lub relatywizację własnego systemu wartości badanych. ${ }^{3}$

Kwestionariusz mapowania świadomości kulturowej objął takie kluczowe obszary (auto)refleksji jak:

- tożsamość/tożsamość wieloraka (pytania otwarte w obu kwestionariuszach $^{4}$ - „Jak określiłby Pan/określiłaby Pani swoją tożsamość narodową/

\footnotetext{
${ }^{3}$ Próbę badawczą stanowiło 14 studentów Uniwersytetu im. Adama Mickiewicza w Poznaniu uczestniczących w wymianie w ramach Erasmus+ w semestrze letnim 2016/2017. W grupie tej ośmiu studentów włączonych zostało do pilotażowej fazy projektu Connect, pozostałych sześciu zaś nie było objętych działaniami projektowymi. Kraje/kultury docelowe reprezentowane w badaniu to: Niemcy (7 studentów), Chorwacja (2 studentów), Portugalia (2 studentów), Szwecja, Włochy oraz Austria (po jednym studencie). Przykłady wypowiedzi studentów i wyniki ich analizy - zob. Chudak, Mackiewicz (2018: 46-57).

${ }^{4}$ Ze względu na ograniczenia objętościowe artykułu, pytania pojawiające się w obu kwestionariuszach a dotyczące tych samych problemów zostały skrócone, lekko zmodyfikowane i ujednolicone. Pytania w drugim kwestionariuszu zawierały częściowo odniesienia do
} 
Techniki ewaluacji kompetencji międzykulturowej: Założenia teoretyczne...

kulturową? Kim Pan/Pani jest? Co leży u podstaw takiego zdefiniowania swojej tożsamości?");

- autostereotypy (pytania otwarte w obu kwestionariuszach - „Z czym kojarzy się Panu/Pani Polska? Proszę uzupełnić asocjogram”, „Proszę wymienić pięć cech Polaków, które spontanicznie przychodzą Panu/Pani do głowy”, „Jakiej cechy Polaków najbardziej Pan/Pani nie lubi?”, „Jaką cechę Polaków Pan/Pani najbardziej ceni");

- heterostereotypy, uprzedzenia (pytania otwarte w obu kwestionariuszach - „Proszę wymienić maksymalnie pięć cech mieszkańców kraju docelowego", "Jakiej cechy mieszkańców kraju docelowego najbardziej Pan/Pani nie lubi?”, „Jaką cechę mieszkańców kraju docelowego Pan/Pani najbardziej ceni?");

- postawy w relacjach międzykulturowych (pytanie otwarte w pierwszym kwestionariuszu - „Czy zastanawiała się Pani/zastanawiał się Pan, co determinuje Pana/Pani zachowanie i komunikację w relacjach z innymi osobami? Skąd wiadomo, jak zareagować czy jaką przybrać postawę?”, pytanie otwarte w obu kwestionariuszach - „Jeżeli dochodzi do napięcia, ewidentnego nieporozumienia lub konfliktu w relacjach zawodowych, akademickich, oficjalnych itp. jaką przyjmuje Pan/Pani postawę wobec tego problemu i innych osób? Co Pan/Pani myśli w takich sytuacjach o zachowaniu drugiej strony konfliktu?");

- antycypacja (pierwszy kwestionariusz) i zreferowanie problemów (drugi kwestionariusz) z dostosowaniem się do kultury kraju docelowego (pierwszy kwestionariusz, pytania zamknięte - „Czy spodziewa się Pan/Pani problemów z dostosowaniem się do kultury kraju docelowego?”, „Jeżeli spodziewa się Pan/Pani problemów z dostosowaniem się do kultury kraju docelowego, to jakiego aspektu będą dotyczyć?”; drugi kwestionariusz, pytania zamknięte - „Czy pojawiły się problemy z dostosowaniem się do kultury kraju docelowego?”, „Jeżeli pojawiły się problemy z dostosowaniem się do kultury kraju docelowego, to jakiego aspektu one dotyczyły?”, pytania otwarte - „Proszę podać jeden przykład najbardziej zaskakującego nieporozumienia/sytuacji konfliktowej z udziałem przedstawicieli miejscowej kultury. Czy z perspektywy czasu rozumie Pan/Pani przyczynę tej krytycznej sytuacji? Czy przypuszcza Pan/Pani, że miała podłoże kulturowe?", "Czy ewentualne problemy z dostosowaniem się do miejscowych wartości,

zakończonego właśnie pobytu za granicą, np.: „Czy pobyt w ramach Erasmus+ wpłynął na Pana/Pani tożsamość kulturową? Kim Pan/Pani jest? Co leży u podstaw ewentualnych modyfikacji swojej tożsamości?" 
zwyczajów, rytuałów itp. dominowały tylko w pewnym okresie, czy towarzyszyły raczej przez cały pobyt?").

Zamkniętemu pytaniu dotyczącemu problemów z dostosowaniem się do kultury kraju docelowego towarzyszyła lista najpowszechniejszych zmian życiowych związanych z kulturowym przemieszczeniem się, takich jak: jedzenie, ubranie, postrzeganie czasu, używany język, zasady higieny, ogólne tempo życia, definicja prywatności, ilość kontaktu fizycznego na co dzień, tematy tabu, życie religijne, pozycja kobiet w społeczeństwie, rytm dnia, wylewność/otwartość ludzi, powściągliwość ludzi, relacje szef-podwładny i/lub wykładowcastudent. Kafeteria miała charakter koniunktywny (możliwość wielokrotnego wyboru), ale uwzględniła także możliwość dopisania innych problemów.

Po fazie pilotażowej podstawowym narzędziem ewaluacji kompetencji międzykulturowej stała się mapa doświadczeń (Experience Map), na której studenci mają możliwość umieszczania postów dotyczących różnych aspektów pobytu za granicą i dzielenia się doświadczeniami (między)kulturowymi (zob. 2.2). W związku ze wspomnianymi wcześniej wątpliwościami dotyczącymi mierzalności kompetencji międzykulturowej w programie Connect zrezygnowano z testów ewaluacyjnych w jakiejkolwiek formie, stawiając nade wszystko na refleksyjność uczestników wymiany studenckiej dokumentowaną na mapie. Także formalny certyfikat ukończenia programu (Certificate of Completion) ${ }^{5}$, nad którym m.in. pracowała grupa robocza d/s certyfikacji tworzona przez Autorów niniejszego artykułu, nie przewiduje w ostatecznej i obowiązującej do chwili obecnej wersji potwierdzenia określonego poziomu tejże kompetencji. Kluczowy fragment tego certyfikatu wskazuje jedynie na udział w poszczególnych częściach programu:

The holder of this certificate participated in different activities within the following parts of the program:

\section{Pre-departure training}

Introduction to Erasmus+ and Connect: intercultural learning sessions on cultural awareness and perception, intercultural communication and acting, intercultural narrative and media competence;

\section{E-learning platform and Experience Map}

Intercultural support before, during and after stay abroad: key concepts in intercultural learning, coping with uncertain situations, experiencing stay

\footnotetext{
${ }^{5}$ Program przewiduje także wydanie certyfikatu uczestnictwa (,Certificate of Participation“) dla osób nieobjętych pełnym cyklem (bez treningu końcowego po powrocie) oraz certyfikatu dla mentorów („Certificate Connect Mentor“).
} 
Techniki ewaluacji kompetencji międzykulturowej: Założenia teoretyczne...

abroad as enrichment, sharing experiences, returning home; sharing experiences on Experience Map;

\section{Re-entry training}

Settling back into home culture: reflection of experiences, reverse cultural shock, internationalization and employability, interculturality at home, becoming a mentor to pass on experiences to peers.

Tak więc rozwój świadomości kulturowej, dzielenie się własnymi przeżyciami i refleksje nad doświadczeniami kulturowymi stanowią kluczowe elementy kształcenia międzykulturowego realizowanego eksplicytnie (w czasie treningów) i implicytnie (poprzez kulturowe wyzwania dnia codziennego za granicą) w ramach programu Connect. Ewaluacja kompetencji międzykulturowej jest zaś w konsekwencji możliwa poprzez analizę autorefleksyjnych wypowiedzi uczestników na forum Experience Map.

Według stanu z 23.02.2020 roku mapa zawiera 872 wpisy, a absolutna ich większość dotyczy wątków „biurokratycznych” (516 wpisów), czyli opisu uczelni wraz z jej jednostkami, biurami, formalnościami czy ofertą dydaktyczną (często po prostu kopiowaną ze stron internetowych uczelni). Część „Links and Material” zawiera najwięcej postów, przy czym większość to linki do stron działów współpracy z zagranicą z poszczególnych szkół wyższych. Z perspektywy ewaluacji kompetencji międzykulturowej, rozumianej jako świadomość i uważność kulturowa oraz zdolność do refleksji międzykulturowej, najważniejsze są wpisy w kategorii „Experiences”. W momencie analizy było ich 79 i zawierały relacje w takich podkategoriach, jak: „My first week”, "Eating at the university", "Conditions of study", "Learning the language”, „Survival tips” czy „More intercultural challenges”. Prawie wszystkie wpisy zostały sformułowane w języku angielskim.

Dla zilustrowania dość wysokiego stopnia międzykulturowej refleksyjności niektórych studentów warto przytoczyć przykładowe wypowiedzi odwołujące się do różnych doświadczeń kulturowych. I tak np. jeden z wpisów z podkategorii „Conditions of study" autorstwa włoskiej studentki przebywającej na uniwersytecie w Vic w Hiszpanii jest refleksją nad różnymi, w jej opinii, metodami pracy na zajęciach i nieco odmiennymi drogami realizowania celów kształcenia ${ }^{6}$ :

It's clearly not the typical university, you learn it from day one: the greatest part of courses mainly rest upon work in group on some project, while exams are usually a marginal part of the learning path. To be honest, I found a little bit difficult meet with my class mates to work together and maybe I also was a little bit prejudiced about this method, but after a while I got used to it and

\footnotetext{
${ }^{6}$ We wszystkich cytatach zachowano tekst oryginalny, poprawiono wyłącznie ew. błędy literowe.
} 
after I came back home i realized that I learned a lot more than i thought and, above all, I learned to work and learn and create with other people: this is something almost impossible in an Economy faculty in Italy. I learned a lot from my experience in Uvic and, although sometimes I hated that University, and I hated how much different its methods were from the one I was accustomed to, the university taught me that team work is the most effective way to success, and also that I still got a lot to learn, mainly not from books.

W podkategorii „Intercultural Challenges” studentka z Niemiec, przebywająca w Mediolanie, zamieściła z kolei dość rozbudowaną relację połączoną z refleksją na temat punktualności. Z pewnością kwestia różnego podejścia do czasu jest istotnym wątkiem w doświadczeniach międzykulturowych, szczególnie, jeżeli dochodzi do zderzenia niemieckiego monochronizmu z włoskim polichronizmem (zob. Gesteland, 2000):

When going abroad I am always aware of the fact of different perceptions of punctuality. And I know myself and how I am. I am the one person that comes to the airport at 5:30 in the morning when I have a flight to catch at 12. Just to make sure. When I am meeting with friends, I usually am 10 minutes too early, so that I can relax and smoke a cigarette before they arrive. I guess it is a cliché that I fulfill for being German, but this is just a custom I have adopted. I don't even mind it a lot when others are late, but in comparison to Italian standards I had a new experience.

So my Italian friend invited me to his birthday party and said that we should be at the meeting point at 20:30. Me and my friend were rushing a bit, because we underestimated the distance to the meeting point. Anyway - knowing that Italians are likely to be a bit late, we came around 20:40. However, there was no one at the meeting point, so I called my friend. He said they are on their way and will be there in around 10 minutes. So, I asked the waiters if we could sit at the table inside, because it was cold and he had made a reservation. But the waiter told me that the reservation was only for 21:00 and that we had to wait until that time to come into the restaurant to sit at the table. My friends finally arrived at 21:10 and felt very sorry that we had to wait so long. But at the same time, we talked about it and he said that he always tells his friends to meet half an hour earlier, because he knows that they will arrive at least $\mathbf{3 0}$ minutes later. So afterwards everything was okay, and I understood, so for the next time I knew better and would not rush anywhere. I think my reaction was quite positive and also because my Italian friend went on exchange to Germany, he knew very well how punctuality can work out in both directions and is understood differently according to the different contexts. He forgot to tell me this in advance, but later it was absolutely no problem. So, my strategy basically was the "Social Support seeking" and in the end everything was okay. We resolved the uneasiness and uncertainty. Because beforehand I knew that Italians are late - but not how late. So that was basically the missing piece of the puzzle for me and now I can decide if I want to arrive 
on time and wait for my Italian friends or if I will just join and try to relax a bit more in that aspect.

Jeden z postów niemieckiej studentki uczącej się w Pekinie (i bardzo aktywnej na Experience Map) dotyczący także wyzwań międzykulturowych i opisuje rozmowy kwalifikacyjne do pracy w banku. Stanowi on ciekawą refleksję nad różnicami w stylu komunikowania pomiędzy zachodnioeuropejskimi a chińskimi kandydatami:

I want to share this experience because it has shown me how much I am influenced by my own perspective in my own thinking. The report shows that despite the knowledge that there are different ways of dealing with situations, I proceed from my expectations of familiar behaviour.

I was asked to do some job interviews for a bank in China with a German friend, to evaluate the German level of the applicants. The recruiting process to get the one-day-job as a person who evaluates the German level of the applicants, was already interesting for me. A Chinese friend of mine asked me, if I would like to do the job. I told her that I wanted to, and she passed me the contact of the responsible person in the bank. The person just texted me and the day I had to do the interviews, I arrived at the bank, together with my friend. There were some other people who would do the same kind of job for different languages. The responsible people passed us some papers without giving any explanation. They were all in Chinese, so we used the translator to have a look what was written on the paper. Some other people who were there, had already done this job in the past and they explained us what to do. We should just evaluate the German level of the applicants by asking questions we could choose. We waited for a long time till we could do the interview with the first person. We did not get any further instruction about what we should ask or how we should evaluate the language level or what kind of job the applicants were applying for. We asked questions like we knew them from German job interviews. For example: "Why do you want to work for this bank?" My friend and I were very surprised about the answers we got from the applicants, because they were very honest to us. The applicants told us for example, that they could earn a lot of money, that they want to come to Beijing to get married and that they would have a save workplace in that bank and wanted the job because of that. When the first person gave that kind of answer, I was very surprised, because I did not expect the applicants to be that honest. Experience has shown me that the answers that are expected in an application process can be very different. If I had had a job interview at that bank and told the interviewers that I wanted to work for the bank because I identified with the values, they probably would have thought me untrustworthy. 
Wypowiedzi tak pogłębione jak w powyższych przykładach mogą dać podstawy do pozytywnego ocenienia rozwoju kompetencji międzykulturowej piszących, szczególnie w jej kognitywnym i refleksyjnym wymiarze. Co ważne, cytowane studentki opublikowały także szereg innych postów, dając jeszcze pełniejszy obraz ich międzykulturowych doświadczeń.

Należy jednak podkreślić, że samo zaoferowanie studentom mapy doświadczeń jako narzędzia do dzielenia się doświadczeniami i przemyśleniami nie gwarantuje jego optymalnego wykorzystania. Gotowość danego studenta czy studentki do podjęcia się spisania swoich doświadczeń i refleksji jest kluczowa zarówno dla rozwoju Experience Map jako źródła informacji dla przyszłych studiujących za granicą, jak i dla możliwości ewaluacji kompetencji międzykulturowej uczestników programów wymiany akademickiej. Czynnikiem motywującym do takiej aktywności może być perspektywa uzyskania opisanego wcześniej certyfikatu oraz zdobycie trzech punktów ECTS za pełnowymiarowy udział w programie.

\section{Wnioski}

Analizy wyników pozyskanych dzięki obu narzędziom: kwestionariuszowi mapowania świadomości kulturowej oraz Experience Map pozwalają na wyciągnięcie kilku wniosków dotyczących rozwoju kompetencji międzykulturowej uczestników wymiany akademickiej oraz potencjału programu Connect dla wspierania tego celu edukacyjnego.

Badanie w grupie pilotażowej poznańskich studentów wskazało na występowanie za granicą rozmaitych zdarzeń zaskakujących lub niezrozumiałych, jednak u wszystkich badanych nie miały one charakteru krytycznego, a "szok kulturowy" nie zawsze był pojęciem adekwatnym do doświadczeń badanych studentów. Badanie jakościowe na tak małej grupie nie pozwala na statystyczne uogólnienia, daje jednak możliwość wychwycenia pewnych zjawisk i sformułowanie wniosków dla tej wyselekcjonowanej grupy:

- dłuższe wcześniejsze pobyty za granicą (co miało miejsce w przypadku osób badanych) redukują efekt szoku kulturowego podczas wymiany Erasmus; pośrednio świadczyć to może także o znaczącym poziomie kompetencji międzykulturowej;

- pokolenie obecnych studentów w wieku 20 lat i starszych uważa różnice kulturowe oraz refleksje na ten temat jako coś oczywistego, a codzienna komunikacja z „Europą” (choćby poprzez internet) pozwala według nich doświadczyć nieustannego (często nieuświadamianego) transferu kulturowego; 
- badani w pierwszym kwestionariuszu zazwyczaj nie antycypują problemów, nie obawiają się możliwych trudności na tle kulturowym;

- kompetencję międzykulturową można próbować mierzyć poziomem refleksyjności osób badanych na temat ich własnej tożsamości, wartości swoich i obcych, przyczyn nieporozumien na tle kulturowym itp.; uczestnicy programu Connect wykazują większą refleksyjność zarówno przed wyjazdem, jak i po powrocie;

- wszyscy badani podają w drugim kwestionariuszu mniej lub bardziej spektakularne przykłady strategii rozwiązywania konfliktów na tle kulturowym; to przesłanka, iż wymiana Erasmus ze wsparciem, ale także bez wsparcia programów szkoleniowo-treningowych, wpływa pozytywnie na rozwój kompetencji międzykulturowej, w tym w wymiarze konatywnym (mobilizującym do działania) i strategicznym.

Omawiane kwestionariusze stanowiły jednorazowe źródło cennych danych na temat wpływu pobytu i studiów za granicą na rozwój świadomości kulturowej i kompetencji międzykulturowej. Experience Map jest z kolei integralnym elementem projektu edukacyjnego Connect i jako narzędzie nieustannie wykorzystywane przez uczelnie partnerskie jest stale powiększającą się bazą wpisów uczestników programów wymiany, głównie Erasmus+. Potencjał tego narzędzia jest z pewnością nie do przecenienia, w optymalnym przypadku stanowi ono bowiem zarówno platformę wymiany doświadczeń i informacji, jak i miejsce, w którym dokonuje się autoewaluacja kompetencji międzykulturowej poszczególnych studentek i studentów. Tym samym setki postów publikowanych na forum mapy to sukcesywnie powiększający się materiał analityczny dla badaczy kompetencji i komunikacji międzykulturowej czy ewaluatorów programów edukacyjnych.

Wydaje się, że treści umieszczone na mapie (przynajmniej do momentu powstania tego artykułu) nie do końca spełniają oczekiwania jej twórców, w tym nasze, jako członków grupy projektowej. Jak sugerowaliśmy wcześniej, kompetencję międzykulturową rozumiemy przede wszystkim jako wysoki poziom refleksyjności nad tym co "swoje” i co "obce”, nad własnymi postawami, strategiami komunikacyjnymi, radzeniem sobie z niejednoznacznościami w interakcjach międzykulturowych itp. Przytoczone trzy wpisy studentek z Włoch i Niemiec są przykładami bogatych w treści relacji, zawierających jednocześnie duży ładunek refleksji (między)kulturowej. Takich, wręcz wzorcowych, osobistych i pogłębionych postów jest niestety mniejszość. Większość studentów ogranicza się do wklejania linków z praktycznymi informacjami i do sformułowania porad zaczerpniętych z własnych doświadczeń. Oczywiście struktura mapy zachęca do umieszczania także tego typu informacji, a opisy realiów życia w innym 
kraju i kulturze są często niezwykle ciekawe i na pewno pomocne dla kolejnych uczestników wymiany. Problemem jest jedynie fakt, że zbyt często osoby relacjonujące swój pobyt na zagranicznej uczelni rezygnują z bardziej pogłębionej refleksji i nie pozostawiają świadectwa rozwoju swojej kompetencji międzykulturowej. Bez wątpienia Experience Map jest odpowiednim narzędziem do wyegzekwowania głębszych przemyśleń nad doświadczeniami kulturowymi i być może zmodyfikowany system motywujący autorów wpisów (np. poprzez inne zasady przyznawania ECTS) zwiększy udział tych prawdziwie refleksyjnych wypowiedzi na forum. Ale to już zadanie poszczególnych uczelni jako uczestników programu Connect.

\section{BIBLIOGRAFIA}

Błażek A. (2008), Evaluation interkultureller Kompetenz bei angehenden Deutschlehrerinnen und -lehrern in Polen. Poznań: Wydawnictwo Naukowe UAM.

Brandenburg U. i in. (2014), The Erasmus Impact Study. Luxembourg: Publications Office of the European Union.

Brandenburg U. i in. (2016), The Erasmus Impact Study. Regional Analysis. Luxembourg: Publications Office of the European Union.

Byram M. (1997): Teaching and assessing intercultural communicative competence. Clevedon: Multilingual Matters.

Chudak S., Mackiewicz M. (2018), „Die Deutschen sind irgendwie anders...” Folgen des Kulturschocks für die kulturelle Identität von polnischen ERASMUSStudierenden: Ergebnisse einer qualitativen Studie, (w:) "GfL-Journal” nr 1/2018, s. 35-67. Online: http://www.gfl-journal.de [DW 10.11.2019].

Chudak S. (2013), Kompetencja medialna uczniów i nauczycieli języków obcych jako czynnik wpływajqcy na poziom ich kompetencji interkulturowej, ,Neofilolog", nr 40/2, s. 219-236.

Dąbrowska-Resiak J. (2018), Erasmus... i co dalej? Badanie losów edukacyjnych i zawodowych polskich studentów uczestniczq̨cych w projektach mobilności w programie Erasmus. Warszawa: FRSE.

Ehrhardt C. (2018), Erasmust: Potential für Lehre und Forschung. Zur Einleitung in den Themenschwerpunkt, ,GfL-Journal”, nr 1/2018, s. 1-14. Online: http://www.gfl-journal.de, [DW 10.11.2019].

Gaworska J. (2017): Pokolenie Erasmusa. Łódź: Wydawnictwo Mrówka.

Gesteland R. (2000): Różnice kulturowe a zachowania w biznesie. Warszawa: Wydawnictwo Naukowe PWN.

Hiller G.G. (2016), Eine Frage der Perspektive. Critical Incidents aus Studentenwerken und Hochschulverwaltung. 30 Fallbeispiele aus der Praxis mit 93 
interkulturellen Einschätzungen von Studierenden und Mitarbeitenden. Berlin: Deutsches Studentenwerk.

Holfter G., Rieder M. (2018), "Things I would have liked to know before" - How to Enhance the Erasmus Experience. "GfL-Journal”, nr 1/2018, http:// www.gfl-journal.de, 68-81. [DW 10.11.2019].

INCA (2004), INCA Assessorenhandbuch - Intercultural Competence Assessment. Online: https://ec.europa.eu/migrant-integration/librarydoc/the -inca-project-intercultural-competence-assessment [DW 30.01.2020].

Karpińska-Musiał B. (2015), Międzykulturowość w glottodydaktyce. Gdańsk: Wydawnictwo Uniwersytetu Gdańskiego.

Kováčová M., Kopčová V. (2018), "Am Anfang war's ein Schock, aber es hat sich gelohnt" - Sprachlernen Philologie- und Nicht-Philologie-Studierender in Erasmus-Aufenthalten. „GfL-Journal”, nr 1/2018, s. 15-34. Online: http://www.gfl-journal.de [DW: 10.11.2019].

Myczko K. (2005): Aktywizacja ucznia w dydaktyce języka obcego: podstawy teoretyczne, (w:) Karpińska-Szaj K. (red.), Nauka języków obcych w dobie integracji europejskiej. Łask: Oficyna Wydawnicza Leksem, s. 229-239.

Myczko K. (2010), Einleitung, (w:) Myczko K. (red.), Reflexion als Schlüsselphänomen der gegenwärtigen Fremdsprachendidaktik. Frankfurt am Main: Peter Lang Verlag, s. 9-11.

Nazarkiewicz K. (2016), Kulturreflexivität statt Interkulturalität? (w:) „Interculture journal. Online-Zeitschrift für interkulturelle Studien", nr 26 (Sonderausgabe: (Inter-) Kulturalität neu denken!), s. 23-32. Online: http://www. interculture-journal.com/index.php/icj/issue/view/37 [DW 10.11.2017].

Schumann A. (red.) (2012), Interkulturelle Kommunikation in der Hochschule. Zur Integration internationaler Studierender und Förderung Interkultureller Kompetenz. Bielefeld: Transkript.

Wilczyńska W., Mackiewicz M., Krajka J. (2019), Komunikacja interkulturowa. Wprowadzenie. Poznań: Wydawnictwo Naukowe UAM. 